\title{
ANALIZA USPJEŠNOSTI KUPNJE KNJIGA ZA FOND SVEUČILIŠNE KNJIŽNICE RIJEKA
}

\author{
THE EFFICACY ANALYSIS OF THE \\ UNIVERSITY OF RIJEKA LIBRARY'S BOOK AQUISITION
}

Sanja Kosić

Sveučilišna knjižnica Rijeka

skosic@svkri.hr

UDK / UDC[024.5/.6: 025.22]: 027.7(497.5 Rijeka)

Izvorni znanstveni rad / Original scientific paper

Primljeno / Received: 13. 9. 2019.

Prihvaćeno / Accepted: 28. 10. 2019.

\section{Sažetak}

Cilj. Sveučilišna knjižnica Rijeka ima na raspolaganju ograničena sredstva namijenjena kupnji knjižnične građe. Cilj je ovoga rada analizom dostupnih podataka o korištenosti građe nabavljene kupnjom utvrditi u kojem je stupnju ta nabava uspješna, odnosno koliko se kupljena građa zaista i koristi te pokušati identificirati razloge nekorištenja.

Pristup/metodologija/dizajn. Na temelju izvještaja o posudbi građe generiranih iz knjižničnog programa provedena je analiza korištenosti građe nabavljene kupnjom. Analiza je provedena na omeđenim publikacijama nabavljenim i korištenim u petogodišnjem razdoblju od 2014. do 2018. godine.

Rezultati. Rezultati analize pokazali su da se najviše nabavlja domaća građa, da sadržajno građa odgovara područjima koja se izučavaju na Sveučilištu te da je vrlo visok postotak građe koja je kupljena za fond Knjižnice zaista i posuđen od strane korisnika.

Ograničenja. Kako Knjižnica kupuje iznimno mali broj serijskih publikacija, analiza je ograničena na kupljene monografije.

Praktična primjena. Metodologiju analize može se primijeniti u knjižnicama koje imaju pristup istim ili sličnim izvorima podataka. Primjenjiva je u knjižnicama koje smatraju potrebnim povremeno procjenjivati uspješnost vlastite nabavne politike, a gledano kroz (ne)korištenje nabavljene građe bez obzira na sam način nabave. Također, rezultate analize može se koristiti kao argument $u$ razgovorima s osnivačem i drugim eventualnim financijerima u nastojanju osiguravanja više sredstava za nabavu, odnosno za prilagodbu vlastite nabavne politike ukoliko se procijeni da je to potrebno.

Vjesnik bibliotekara Hrvatske 62, 2(2019), 131-148

ISSN 0507-1925 
Originalnost/vrijednost. Uobičajeno metode vrednovanja knjižničnih zbirki promatraju zbirku, odnosno cjelokupni knjižnični fond kao cjelinu bez obzira na sam način nabave građe. Provedena analiza fokusirana je pak na građu nabavljenu na određeni način, bez obzira na to u koju je zbirku ta ista građa uvrštena, a nastojeći procijeniti jesu li dostupna sredstva utrošena na najbolji mogući način, i to s aspekta korisnika.

Ključne riječi: analiza korištenosti knjiga, kupnja knjiga, Sveučilišna knjižnica Rijeka, vrednovanje knjižničnog fonda

\section{Abstract}

Purpose. The University of Rijeka Library has limited financial funds for the acquisition of library materials at their disposal. Based on the existing data on the purchased books usage statistics, this paper aims to determine the efficacy of these acquisitions, that is, if the library users have really borrowed the purchased books. Furthermore, the paper will try to identify the books that were purchased but not borrowed and explore the reasons why they were not borrowed.

Approach/methodology/design. Based on the reports of the book loans generated by the library software, the usage analysis of the purchased books has been carried out. The analysis was conducted on the monographs which were purchased and borrowed in the period between 2014 and 2018.

Findings. The results show that in the researched period mostly domestic books were purchased. The topics and the content of the acquired books correspond to the study programs of the University of Rijeka. High percentage of the purchased books have been borrowed later by the library users.

Research limitations/implications. Since the University of Rijeka Library is purchasing only a small number of serial titles, this analysis is limited to the purchased monographs only.

Practical implications. The methodology of the analysis can be applied in libraries that can procure the same or similar data reports. It is applicable in the libraries that consider necessary the evaluation of their own acquisition policies from time to time, taking into consideration the usage data on all acquired materials, regardless of the acquisition methods. The analysis results can be used as an argument in the negotiations with the library founders and any other potential library financiers. They can also be used to revise and adjust library acquisition policies.

Originality/value. Usually, the collection evaluation methods are used on the entire collections or the library holdings as the whole, regardless of the acquisition methods. This analysis was focused on the books acquired by the specific method, regardless of the library collection each item belongs to. It is intended to explore and evaluate if the financial means were used in the most efficient way, but viewed from the users' perspective.

Keywords: book acquisition, books usage analysis, collection evaluation, The University of Rijeka Library 


\section{Uvod}

Sveučilišna knjižnica Rijeka (SVKRI) sustavno izgrađuje svoj knjižnični fond i upravlja njime. Građu za fond Knjižnica nabavlja kupnjom, darovima, zamjenom i obveznim primjerkom koji prima i pohranjuje na temelju odredbi Zakona o knjižnicama i knjižničnoj djelatnosti. ${ }^{1} \mathrm{Kroz}$ institut obveznog primjerka Knjižnica zaprima najveći dio građe za fond. ${ }^{2}$ Ostali oblici nabave građe bitno su manje zastupljeni u ukupnom broju prinova. No za razliku od prihvata i pohrane obveznog primjerka, koji su definirani Zakonom, nabava građe kupnjom, darovima i zamjenom dio je procesa izgradnje fonda na koji Knjižnica ima više utjecaja.

Nakon što je građa nabavljena i uvrštena $u$ fond, ona kao njegov dio postaje predmetom vrednovanja. U postupku vrednovanja knjižničnih zbirki moguće je koristiti brojne metode i tehnike, a sam izbor ovisi o cilju, svrsi i izvedivosti vrednovanja te raspoloživim resursima i primjenjivosti rezultata vrednovanja. ${ }^{3}$ P. Johnson metode vrednovanja dijeli na kvantitativne i kvalitativne, a potom i ovisno o tome jesu li utemeljene u korištenju, odnosno korisnicima ili pak u samoj zbirci. ${ }^{4}$

Područje vrednovanja u knjižničnom poslovanju vrlo je zanimljivo već dulji niz godina te u ovom području u Hrvatskoj nastaje sve veći broj radova. O samoj kulturi vrednovanja u visokoškolskim knjižnicama i mogućim pristupima vrednovanju svih aspekata poslovanja visokoškolske knjižnice u svojoj knjizi govori K. Petr Balog. ${ }^{5}$ Utvrđivanjem uspješnosti poslovanja visokoškolskih knjižnica u svojoj disertaciji bavila se M. Ambrožič. ${ }^{6}$

No područje vrednovanja knjižničnih zbirki ipak je manje zastupljeno u domaćoj literaturi. M. Mišetić u svom doktorskom radu govori i o vrednovanju filološke zbirke u suvremenoj visokoškolskoj knjižnici. ${ }^{7} \mathrm{O}$ vrednovanju pojedinih zbirki korištenjem citatne analize pisale su S. Faletar Tanacković, M. Junušić i I. Faletar ${ }^{8}$ te K. Ro-

\footnotetext{
1 Zakon o knjižnicama i knjižničnoj djelatnosti. // Narodne novine 181, 17(2019). Čl. 39. [citirano: 2019-08-26]. Dostupno na: https://narodne-novine.nn.hr/clanci/sluzbeni/2019_02_17_356.html.

2 Prema podacima za 2017. godinu, $87 \%$ omeđenih i $93 \%$ serijskih publikacija Knjižnica je zaprimila kao obvezni primjerak. Izvor: Godišnji popis prinova Sveučilišne knjižnice Rijeka za 2017. godinu (interni dokument).

3 Mišetić, M. Vrednovanje filološke knjižnične zbirke u suvremenoj visokoškolskoj knjižnici: doktorski rad. Zagreb: M. Mišetić, 2017. Str. 55.

4 Johnson, P. Fundamentals of collection development and management. 3rd ed. London: Facet publishing, 2014. Str. 302.

5 Petr Balog, K. Prema kulturi vrednovanja u visokoškolskim knjižnicama. Osijek: Filozofski fakultet Sveučilišta, 2010.

6 Ambrožič, M. Utvrđivanje uspješnosti poslovanja visokoškolskih knjižnica: od kvantitativnih do kvalitativnih pokazatelja: doktorska disertacija. Zagreb: M. Ambrožič, 1999.

7 Mišetić, M. Nav. dj.

8 Faletar Tanacković, S.; M. Junušić; I. Faletar. Vrednovanje knjižničnog fonda uz pomoć citatne analize na primjeru zbirke iz informacijskih znanosti u Knjižnici Filozofskog fakulteta u Osijeku. // Libellarium 5, 1 (2012), 71-88. [citirano: 2019-08-30]. Dostupno na: https://hrcak. srce.hr/97453.
} 
mić i G. Mitrović. ${ }^{9}$ Utjecaj samih zbirki sveučilišnih knjižnica na akademski uspjeh studenata istraživale su I. Morić Filipović i M. Dragija Ivanović. ${ }^{10}$ Kvantitativne podatke o kupnji građe namjenskim sredstvima osnivača te probleme osiguravanja sredstava u svom je radu predstavila T. Grujić. ${ }^{11}$ Ipak, općenito je u Hrvatskoj mali broj radova koji se bave sustavnom analizom knjižničnih zbirki, odnosno knjižničnog fonda, što može upućivati na to da se takve analize često ne provode, barem u visokoškolskim knjižnicama, na što su upozorile i T. Krajina i H. Markulin. ${ }^{12}$

U stranoj je literaturi, posebno u časopisima koji su dostupni u bazama podataka, moguće pronaći veći broj radova koji se bave vrednovanjem knjižničnih zbirki. M. Hyödynmaa sa suradnicima je istraživala mapiranje zbirki kao način evaluacije knjižnične zbirke. ${ }^{13}$ Obrasce u posudbi građe kroz razdoblje od 15 godina analizirali su S. Cheung, T. Chung i F. Nesta ${ }^{14}$, dok su G. Prathap i R. Mittal ${ }^{15}$ istraživali mogućnosti mjerenja i evaluacije knjižnične statistike o cirkulaciji građe s naglaskom na korištenju građe prema sadržaju. Svakako treba spomenuti i rad J. Renauda i suradnika koji su prikupili i uparili podatke iz različitih izvora (knjižničnu statistiku i izvješća iz programa, podatke iz raznih registara i kadrovske službe sveučilišta) te analizirali korištenje knjižničnih resursa u razdoblju od 20 godina, a istraživali su i korelaciju između korištenja knjižnice i akademskog uspjeha studenata. ${ }^{16}$

Iako se spomenuti radovi ne bave vrednovanjem građe prema načinu nabave, oni su svakako važni i primjenjivi i u ovom slučaju. Treba imati na umu to da u

\footnotetext{
9 Romić, K.; G. Mitrović. Vrednovanje knjižničnog fonda: na primjeru zbirke disertacija i magistarskih radova u Nacionalnoj i sveučilišnoj knjižnici u Zagrebu uz pomoć citatne analize. // Vjesnik bibliotekara Hrvatske 59, 3-4(2016), 47-62. [citirano: 2019-08-30]. Dostupno i na: https:// hrcak.srce.hr/187570.

10 Morić Filipović, I.; M. Dragija Ivanović. Vrednovanje utjecaja sveučilišnih knjižnica u Hrvatskoj:istraživanje utjecaja zbirki i usluga sveučilišnih knjižnica na akademski uspjeh studenata. // Vjesnik bibliotekara Hrvatske 54, 4(2011), 1-12. [citirano: 2019-08-30]. Dostupno i na: https:// www.hkdrustvo.hr/vjesnik-bibliotekara-hrvatske/index.php/vbh/article/view/337/332.

11 Grujić, T. Nabava literature za potrebe Sveučilišta u Puli - možemo i bolje! // Knjižnice: kamo i kako dalje? / 13. dani specijalnih i visokoškolskih knjižnica. Zagreb: Hrvatsko knjižničarsko društvo, 2014. Str. 309-318.

12 Krajina, T.; H. Markulin. Nabava knjižnične građe u visokoškolskim knjižnicama. // Vjesnik bibliotekara Hrvatske 54, 3(2011), str. 34. [citirano: 2019-08-29]. Dostupno i na: https://hrcak. srce.hr/80101.

13 Hyödynmaa, M.; A. Ahlholm-Kannisto; H. Nurminen. How to evaluate library collection: a case study of collection mapping. // Collection Building 29, 2(2010), 43-49. DOI: https://doi. org/10.1108/01604951011040125.

14 Cheung, S.; T. Chung; F. Nesta. Monograph circulation over a 15-year period in a liberal arts university. // Library Management 32, 6/7(2011), 419-434. DOI: https://doi. org/10.1108/01435121111158565.

15 Prathap, G.; R. Mittal. A performance index approach to library collection. // Performance Measurement and Metrics 11, 3(2010), 259-265. DOI: https://doi.org/10.1108/14678041011098532. 16 Renaud, J.; S. Britton; D. Wang; M. Ogihara. Mining library and university data to understand use patterns. // The Electronic Library 33, 3(2015), 355-372. DOI: https://doi.org/10.1108/EL-07-2013-0136.
} 
Hrvatskoj samo određene knjižnice primaju obvezni primjerak, dok ostale svoj fond ipak u najvećoj mjeri izgrađuju upravo kupnjom koja se financira iz različitih izvora. Stoga je svim knjižnicama svakako važno periodično procjenjivati koliko su u vlastitoj nabavnoj politici uspješne, posebno gledajući s aspekta korisnika.

\section{Kupnja građe za fond SVKRI}

Kupnja građe za knjižnični fond provodi se u okviru financijskih mogućnosti Knjižnice. Sredstva kojima Knjižnica raspolaže za tu svrhu vrlo su ograničena. Na nacionalnoj razini nije riješeno sustavno financiranje nabave građe za fond sveučilišnih knjižnica, pa tako ni za SVKRI. Stoga se u SVKRI financijska sredstva za nabavu građe osiguravaju iz doznačenih namjenskih sredstava osnivača, iz sredstava projekata koje Knjižnica provodi te iz dostupnih vlastitih sredstava. Pritom sredstva koja Knjižnici doznačuje osnivač nisu vezana uz neki oblik koordinirane nabave građe za sve knjižnice na Sveučilištu. Sastavnice Sveučilišta, kao zasebne pravne osobe, samostalno odlučuju o sredstvima koja će utrošiti u nabavu građe.

Sveučilište u Rijeci niz godina Knjižnici, kao dio sveučilišne politike osiguranja pristupa izvorima za učenje ${ }^{17}$, doznačuje namjenska sredstva za nabavu literature namijenjene studentima (ispitna i seminarska literatura). Samim time što se radi o sredstvima iz studentskih upisnina, njihova je namjena osigurati studentima pristup literaturi potrebnoj za rad te se prema tome određuju naslovi i primjerci za kupnju. U ukupnom obujmu kupnje građe za SVKRI najveći se dio nabavlja upravo iz tih sredstava.

Osim iz sredstava osnivača, sredstva za nabavu Knjižnica osigurava i iz projekata u kojima sudjeluje. Tako se kroz projekt Američkog kutka ${ }^{18}$ u SVKRI niz godina nabavljala knjižnična građa. Valja napomenuti da je kod svakog korištenja projektnih sredstava za nabavu knjižnične građe u pravilu samim projektom i njegovim ciljevima više ili manje određeno kakva će se građa nabavljati.

Naposljetku, kupnja građe financira se i iz vlastitih sredstava, no kako knjižnice po svojoj prirodi nisu profitne ustanove, ta su sredstva prilično oskudna.

Upravo zbog ograničenih sredstava raspoloživih za nabavu potrebno je voditi računa o tome na koji se način ona troše. U tu svrhu SVKRI je 2016. godine usvojila interne smjernice za rad pod nazivom Kriteriji i postupak kupnje knjižnične građe za fond Sveučilišne knjižnice Rijeka ${ }^{19}$ kojim su definirani izvori financiranja, vrste građe koje se kupuju, prioriteti, postupci prikupljanja potreba za nabavu građe i djelatnici odgovorni za provođenje pojedinih aktivnosti. Kao prioriteti za

\footnotetext{
17 Sveučilište u Rijeci. Strategija 2014.-2020. [citirano: 2019-08-26]. Dostupno na: https://uniri. hr/wp-content/uploads/2019/03/Strategija_UNIRI_2014_2020_HR.pdf.

18 Sveučilišna knjižnica Rijeka. O Američkom kutku. [citirano: 2019-08-26]. Dostupno na: https://svkri.uniri.hr/portal/index.php/component/content/category/14-acri.

19 Sveučilišna knjižnica Rijeka. Kriteriji i postupak kupnje knjižnične građe za fond Sveučilišne knjižnice Rijeka: smjernice za rad. Interni akt usvojen 01. veljače 2016. Dostupno u arhivi Sveučilišne knjižnice Rijeka
} 
kupnju građe, uzimajući u obzir dostupna sredstva, njihov izvor te strukturu i potrebe korisnika, određeni su

- ispitna (obvezna i dopunska) i seminarska studentska literatura

- građa koja svojim sadržajem odgovara područjima koja se proučavaju na Sveučilištu u Rijeci, a koju Knjižnica ne posjeduje ili posjeduje samo obvezni primjerak

- građa koja je putem međuknjižnične posudbe više puta zatražena od drugih knjižnica

- građa koja se opetovano pojavljuje na listi rezerviranih primjeraka

- građa namijenjena Referentnoj zbirci (rječnici, leksikoni, priručnici i sl.)

- ostala građa koja pripada zbirci Croatica, a koju Knjižnica ne posjeduje ili posjeduje samo obvezni primjerak.

Uobičajeno se podaci o potrebnoj ispitnoj i seminarskoj literaturi prikupljaju iz predmetnih silabusa te bilježenjem zahtjeva samih studenata i znanstveno-nastavnog osoblja. Zahtjevi za međuknjižničnom posudbom redovito se bilježe i provjeravaju, a jednako se čini i s rezervacijama. Ipak, svaki zahtjev ponovno procjenjuje stručno osoblje Knjižnice prije donošenja odluke o kupnji.

\section{Istraživanje korištenosti kupljene građe}

SVKRI za fond kupuje sve vrste građe, no na serijske publikacije pritom otpada vrlo mali dio (godišnje se obnavlja pretplata na samo pet naslova). Za korisnike Knjižnice pokazalo se dostatnim što su znanstveni i stručni časopisi dostupni na platformi Hrčak u otvorenom pristupu te što je omogućen pristup inozemnim časopisima u bazama podataka kroz nacionalnu licencu. Stoga je istraživanje provedeno na monografijama koje su kupljene i korištene u razdoblju od 2014. do 2018. godine.

\subsection{Izvori podataka i metodologija istraživanja}

Kako bi se provelo istraživanje korištenosti, bilo je potrebno izdvojiti kupljenu građu koja je predmet istraživanja. Iz knjižničnog programa Crolist generirana je inventarna knjiga svih monografija prinovljenih u fond Knjižnice u promatranom razdoblju. ${ }^{20}$ Inventarna knjiga generira se u formatu $x l s$ što omogućava jednostavno manipuliranje podacima u njoj. Generirana inventarna knjiga sadrži sljedeće podatke: inventarni broj ${ }^{21}$, datum inventarizacije, podatak o naslovu, autoru, ISBN-broju, mjestu izdanja i izdavaču, godini izdanja, dobavljaču, vrijednosti i signaturi.

\footnotetext{
20 U programu Crolist inventarna knjiga za pojedino razdoblje generira se korištenjem putanje 4. Posudba - 7. Statistike - I. Inventarna knjiga.

${ }^{21}$ Inventarni broj sastoji se od slovne oznake (iz koje se vidi način nabave, vrsta građe te radi li se o domaćem ili stranom izdanju), rednog broja i godine inventarizacije.
} 
Podaci dostupni u inventarnoj knjizi potom su ručno dopunjeni podacima iz izvještaja Lista posuđivanih primjeraka po inventarnom broju. ${ }^{22} \mathrm{Uz}$ svaki je inventarni broj dodan broj posudbi u promatranom razdoblju te lokacija. Potom je za svaki svezak dodan UDK-broj ${ }^{23}$ kako bi se kupljena građa mogla razvrstati i prema sadržaju.

Iz priručnih evidencija koje djelatnici Knjižnice angažirani u nabavi građe stvaraju u postupku kupnje $\mathrm{e}^{24}$, u tablicu su za svaki pojedini svezak dodani podaci o tome radi se li o naslovu prinovljenu kupnjom ili dodatnom primjerku naslova koji je od ranije dostupan $u$ fondu te napomena je li primjerak zatražen od strane korisnika ili djelatnika knjižnice.

Kako bi se podaci o kupljenoj građi stavili u kontekst u kojem Knjižnica djeluje, korišteno je izvješće koris_anal ${ }^{25}$ u kojem su dostupni podaci o korisnicima koji su učlanjeni u Knjižnicu u promatranom razdoblju, o vrsti korisnika ${ }^{26}$ kojoj pripadaju i ustanovi u kojoj su zaposleni, odnosno gdje studiraju. Ti su podaci stavljeni u vezu s ukupnim brojem studenata po sastavnicama ${ }^{27}$ jer je najveći dio raspoloživih sredstava za kupnju građe namijenjen upravo njima, a kasnije se vežu i uz podatke o kupljenoj građi prema njezinu sadržaju.

Nakon popunjavanja tablice pristupilo se analizi dostupnih podataka polazeći pritom od dvije pretpostavke:

- građa kupljena za fond SVKRI u najvećem se dijelu koristi i

- građa čiju su kupnju zatražili sami korisnici često je korištena.

Kako se istraživanjem proučava i ocjenjuje uspješnost provođenja kupnje monografija, kao temeljna mjera uspješnosti uzet je jednostavan kriterij - da je kupljena građa barem jednom zadužena od strane korisnika. Pritom su iz analize korištenosti isključene monografije smještene u Referentnu zbirku. Naime Referentna zbirka SVKRI smještena je u otvorenom pristupu u čitaonicama Knjižnice i njome se korisnici koriste kroz cijelo radno vrijeme knjižnice bez potrebe za

22 Izvješce je dostupno u programu Crolist kroz putanju 4. Posudba - 5. Upiti/Statusi - P. Lista posuđivanih primjeraka po inv. broju. Iz izvješća je za svaki pojedini inventarni broj (primjerak građe) vidljiv broj posudbi u zadanom razdoblju, naslov, autor, mjesto izdanja i izdavač, godina izdanja, signatura i lokacija primjerka.

${ }^{23}$ UDK-broj preuziman je iz kataložnih zapisa za svaki nabavljeni primjerak, no samo do treće znamenke.

24 Internim je procedurama određen način na koji se bilježi građa za kupnju u desideratu te način na koji se bilježi status svakog pojedinog naručenog primjerka. Rezultat je tablica iz koje je za svaki primjerak moguće dobiti podatke o tome tko je tražio i odobrio kupnju, kada je izvršena narudžba, koji je dobavljač te cijena svakog pojedinog primjerka.

25 Izvješće koris_anal generira se postavljanjem SQL-upita u bazu.

26 Npr. studenti, znanstveno-nastavno osoblje, građani itd.

${ }_{27}$ Sveučilište u Rijeci. Broj studenata u 2018./19. ak. godini. [citirano: 2019-09-10]. Dostupno na: https://rektor.uniri.hr/files/SVE\%20GODINE\%20STUDIJA\%202018_2019\%20tab\%20zavrsna\%20za\%20web.pdf. 
zaduživanjem. Jedini način za praćenje korištenosti Te građe bilo bi promatranje i analiza građe koja je odložena i čeka ponovno ulaganje na police, odnosno promatranje stanja u kojem se fizički primjerak nalazi, što nije bilo predmet ovog istraživanja. $U$ analizi dostupnih podataka kombinirane su kvalitativne i kvantitativne metode u vrednovanju zbirki, a građa koja je predmet istraživanja analizirana je $\mathrm{s}$ aspekta korištenja, odnosno korisnika.

\subsection{Rezultati istraživanja}

Kada su podaci prikupljeni, pristupilo se njihovoj analizi. Kupljene monografije razvrstane su ovisno o tome radi li se o domaćim ili inozemnim izdanjima pa je na slici 1. prikazan ukupno nabavljen broj svezaka monografija u promatranom razdoblju. Vidljiva je prevaga domaće građe u kupnji, no taj je rezultat potpuno očekivan uzimajući u obzir to da je najveći dio monografija namijenjen studentima te da se, osim nekoliko novijih studijskih programa, nastava na Sveučilištu u Rijeci izvodi na hrvatskom jeziku. Također, vidljivo je da je veća količina strane građe nabavljana 2014. i 2015., dok u sljedećim godinama dolazi do znatnog pada. U 2014. i 2015. još uvijek je u SVKRI djelovao Američki kutak te je u okviru provođenja tog projekta nabavljana strana građa. Krajem 2015. projekt završava, što se odražava i na broj nabavljenih stranih naslova, ali i na broj ukupno nabavljene građe.

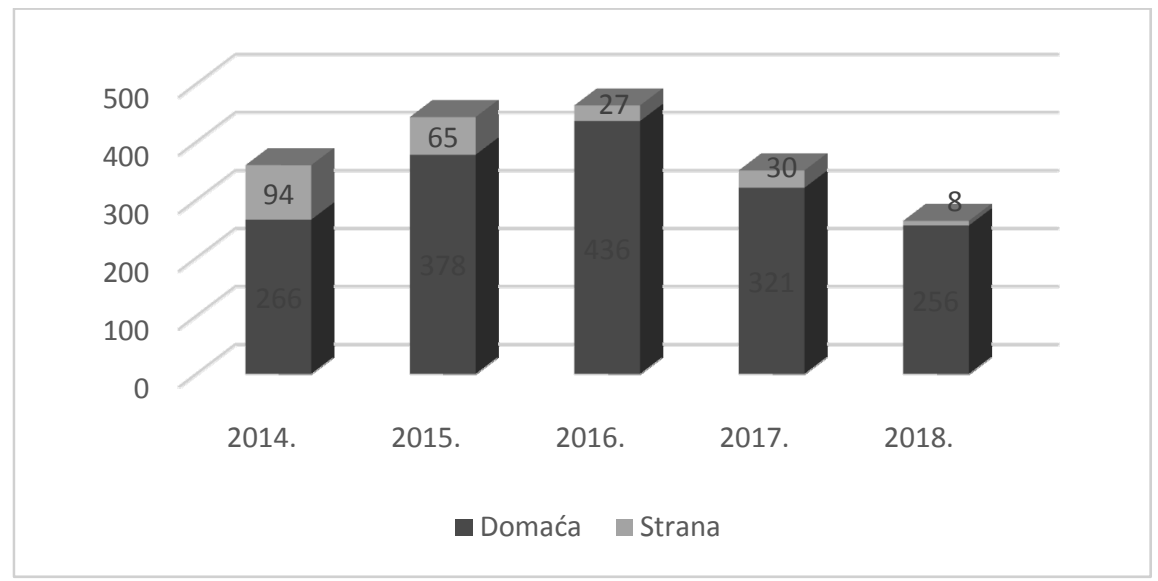

Slika 1. Broj nabavljenih svezaka domaće i strane građe u razdoblju od 2014. do 2018.

Na jednak način kao što se u promatranom razdoblju povećavao, odnosno smanjivao broj kupljenih primjeraka, povećavala su se i smanjivala ukupna dostupna sredstva za nabavu knjižnične građe. 
Sadržajna struktura svih nabavljenih monografija prema osnovnim UDK-skupinama prikazana je na slici 2. Najveći postotak građe nabavljen je u području UDK-skupine 6, koja obuhvaća primijenjene znanosti, medicinu, tehniku i tehnologiju. Potom slijede monografije iz područja društvenih znanosti, ekonomije, prava i obrazovanja (skupina 3 ) te iz područja jezika, lingvistike i književnosti (skupina 8).

Daljnjom analizom utvrđeno je da je unutar skupine 6 najviše građe nabavljeno iz područja medicinskih znanosti (72\%), inženjerstva, tehnike i tehnologije (11\%) i ekonomike kućanstva (11\%). Unutar skupine 3 najviše je monografija iz područja prava (30\%), obrazovanja (30\%) i ekonomije (13\%). U skupini 8 najveći je dio monografija nabavljen iz područja književnosti (73\%), dok je $26 \%$ monografija iz područja lingvistike.

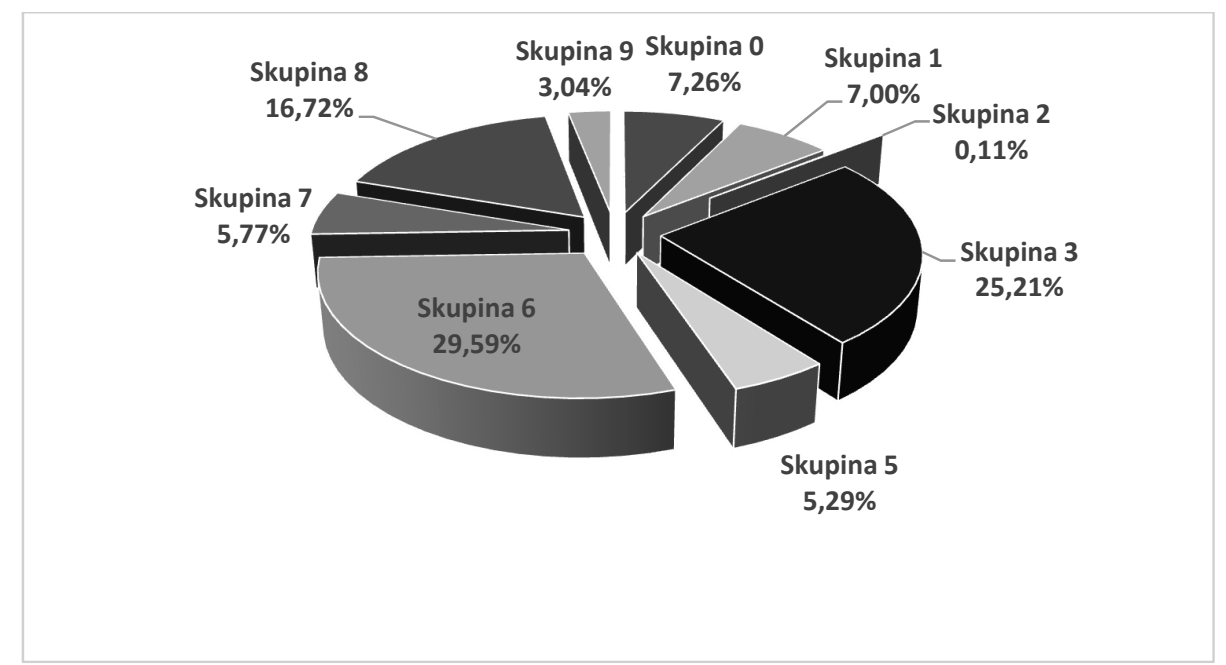

Slika 2. Nabavljene monografije prema osnovnim UDK-skupinama

Sadržajna struktura nabavljene građe odgovara strukturi studenata korisnika SVKRI prema pripadnosti pojedinim sastavnicama Sveučilišta u Rijeci. Slika 3 daje prikaz strukture studenata članova SVKRI prema pripadnosti pojedinoj sastavnici Sveučilišta u odnosu na ukupan broj studenata na pojedinoj sastavnici, pri čemu su u broj studenata po sastavnicama uključene sve razine studija. Najveći broj studenata članova SVKRI dolazi s Filozofskog (FFRI), Medicinskog (MEDRI) i Pravnog fakulteta (PRAVRI), no to nisu najveće sastavnice Sveučilišta prema ukupnom broju studenata. Najviše studenata na Sveučilištu u Rijeci, neovisno o razini studija, pohađa Tehnički (RITEH) i Ekonomski (EFRI) fakultet te Fakultet za menadžment u turizmu i ugostiteljstvu (FMTU). 


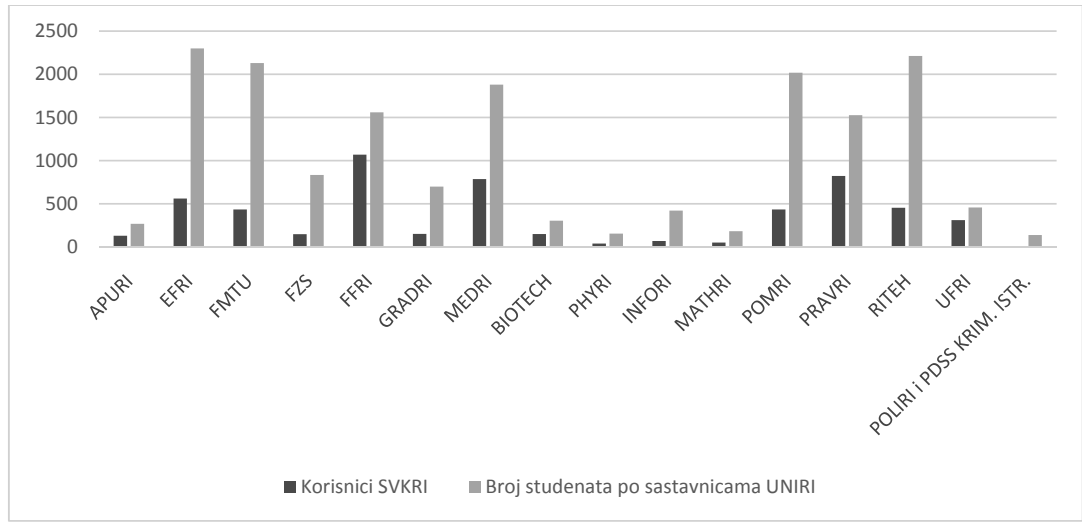

Slika 3. Broj studenata po pojedinim sastavnicama Sveučilišta u Rijeci ${ }^{28}$ i broj studenata korisnika SVKRI prema pripadnosti sastavnici

Nastavno na odnos sadržaja nabavljenih monografija i strukturu studenata na Sveučilištu, na slici 4 prikazana je struktura kupljenih svezaka prema skupinama UDK, a koji su posuđeni više od 10 puta (češće korištena građa). Vidljivo je da najveći dio otpada na građu iz skupine 6 , pri čemu 80 \% otpada na građu koja se odnosi na medicinske znanosti. Činjenica da je najposuđivanija kupljena građa iz područja medicinskih znanosti podudara se s time što je građa iz tog područja najposuđivanija i na razini cijelog fonda SVKRI, bez obzira na način nabave. Tako je u promatranom razdoblju $42 \%$ od pedeset najposuđivanijih naslova upravo iz područja medicinskih znanosti. Također, svakako valja uzeti u obzir da građa iz tog područja ima prilično visoku jediničnu cijenu sveska u nabavi, što studentima svakako može predstavljati problem te će češće pokušavati literaturu nabaviti u knjižnici.

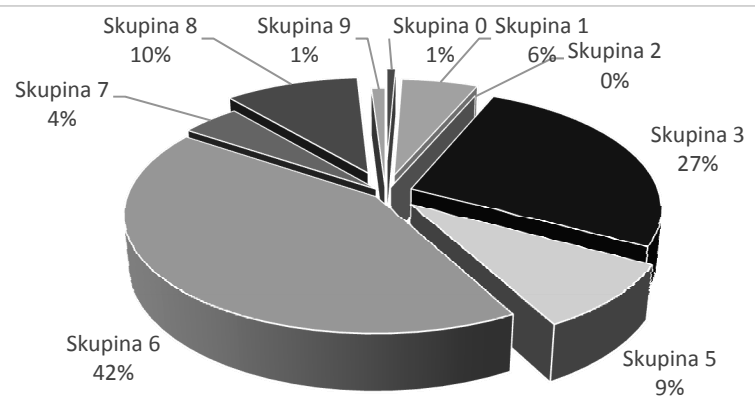

Slika 4. Najposuđivanija građa prema skupinama UDK

28 Sveučilište u Rijeci. Broj studenata u 2018./19. ak. godini. Nav. dj. 
Na slici 5 kupljena građa prikazana je također prema UDK-skupinama s obzirom na to je li korištena ili nije. Ukupan broj i struktura po skupinama odgovaraju prikazanome na slici 2, no iz donjeg je prikaza vidljivo na koja se područja odnosi građa koja je nabavljena, ali koja potom nikada nije zatražena od strane korisnika. Iz prikaza je isključena građa nabavljena za Referentnu zbirku SVKRI jer se ona ne zadužuje, već ju korisnici slobodno koriste u prostoru čitaonica.

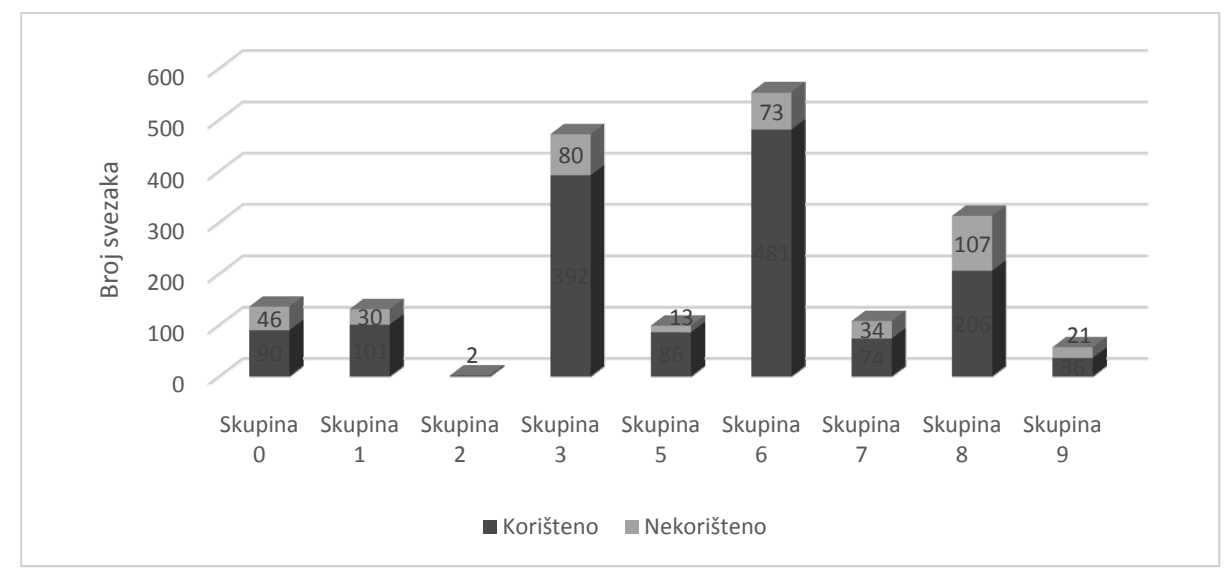

Slika 5. Kupljena korištena i nekorištena građa prema UDK-skupinama

U prikaz na slici 5 uključena je i građa nabavljena 2018. iako je ta građa, posebno ona nabavljena na samom kraju godine, imala kraće razdoblje u kojem ju je korisnik mogao zatražiti i posuditi. Najveći jedinični broj neposuđenih primjeraka otpada na skupinu 8 , a unutar nje na književnost.

Sve prinove koje su kupljene na slici 6 raspoređene su ovisno o tome radi li se o kupljenom primjerku naslova koji već postoji u fondu SVKRI, odnosno o sasvim novom naslovu koji prvi puta dolazi u fond. Iz slike se jasno vidi kontinuirani pad broja nabavljenih novih naslova. Dijelom se to može povezati s prestankom rada Američkog kutka jer se za tu zbirku nisu kupovali dodatni primjerci. Osim toga, razlog treba tražiti u činjenici da su raspoloživa sredstva s godinama smanjivana, što je doveo do toga da se u odluci o kupnji bira „,sigurnija“ opcija, odnosno nabava dodatnih primjeraka naslova koji već postoje u fondu, a korisnici ih trebaju i traže. 


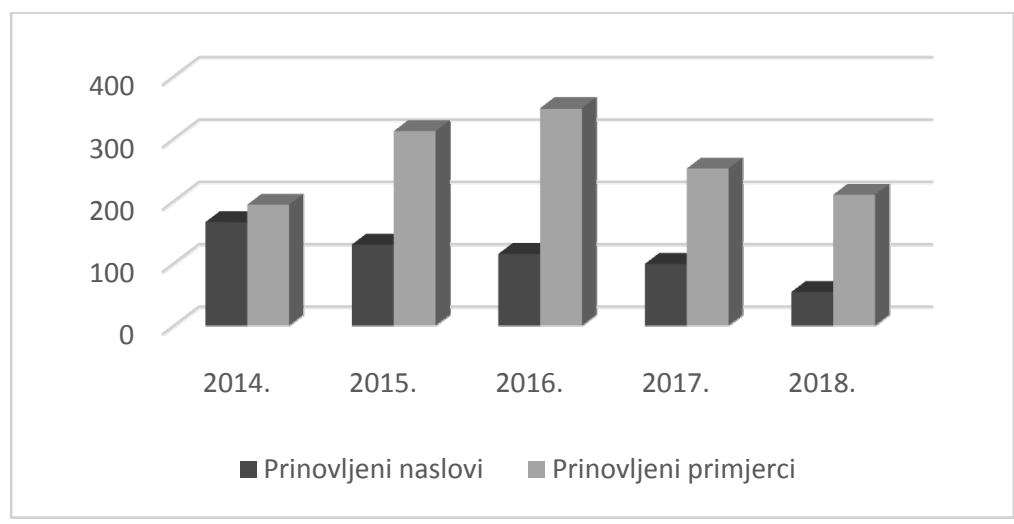

Slika 6. Broj kupnjom prinovljenih naslova i primjeraka

Daljom analizom neposuđenih novih naslova i primjeraka prema sadržaju (UDK-skupinama) utvrđeno je da najveći broj prinovljenih naslova koji kasnije nisu zatraženi od strane korisnika sadržajem pripada UDK-skupini 8 (48 \%), dok je najmanje takvih naslova iz područja skupine 6 (4\%).

Kada se promatra broj kupljenih dodatnih primjeraka naslova koji su od ranije postojali u fondu, a koji se nakon kupnje nisu koristili, prednjači građa domaćih izdavača (72\%), dok na stranu građu otpada $28 \%$. S obzirom na ukupnu strukturu nabave i činjenicu da se u najvećem dijelu nabavlja građa domaćih izdavača, takav je rezultat i očekivan. Od ukupno nekorištene strane građe, 39 \% odnosi se na građu nabavljenu namjenskim sredstvima osnivača, dok se ostatak odnosi na nabavljeno sredstvima projekata ili vlastitim sredstvima.

$\mathrm{Na}$ nekorištene primjerke nabavljene građe otpada $27 \%$ od ukupno nabavljenih monografija u promatranom razdoblju. Ukoliko se iz ukupnog broja, zbog ranije već spomenutih razloga, izdvoji građa namijenjena Referentnoj zbirci, taj postotak iznosi $17 \%$. Iako korištenost građe na razini od $83 \%$ jest vrlo dobra, s obzirom na činjenicu da su financijska sredstva jako ograničena, iznimno je važno ispitati razloge koji stoje iza nekorištenja.

Stoga se pristupilo provjeri zahtjeva za nabavu svakog primjerka koje u svom radu popunjavaju djelatnici koji se bave nabavom građe kako bi se utvrdilo jesu li zahtjevi za nekorištenu građu postavljeni od strane korisnika ili su prijedlog djelatnika. Za posljednje dvije promatrane godine, 2017. i 2018., sustavno se na jasniji način bilježio razlog prijedloga za nabavu, odnosno predlagatelj. Za potrebe ovog istraživanja kao zahtjev korisnika uzima se svaki postavljeni izravni zahtjev korisnika za nabavom primjerka, zahtjevi znanstveno-nastavnog osoblja te napomene djelatnika da su potrebni dodatni primjerci, u pravilu udžbeničke literature, jer su svi postojeći posuđeni, a korisnici ih i dalje traže. Svi ostali zahtjevi za nabavu tretiraju se kao prijedlog djelatnika SVKRI, uključujući prijedloge za nabavu temeljene na predmetnim silabusima. 
Uparivanjem podataka iz priručnih evidencija s ranije formiranom bazom podataka za analizu, dolazi se do zaključka da je $62 \%$ tih zahtjeva došlo od strane korisnika. Taj je podatak iznenadio i njime je pobijena pretpostavka, pod kojom se krenulo u istraživanje, da je građa koju su zatražili korisnici korištena u vrlo visokom postotku. O razlozima za nastanak takve situacije svakako se treba zapitati.

Iako je jedini način da se sazna točan razlog nekorištenja naručene građe samo traženje odgovora od korisnika, u trenutku provođenja ovog istraživanja to nije bilo moguće. Takvo istraživanje zahtijevalo bi dobru pripremu, no ono će svakako biti provedeno u budućnosti. Dotad se kao moguće razloge može razmotriti sljedeće:

- Predugo vrijeme čekanja na naručeni primjerak - iako se domaće publikacije nabavljaju brzo (u pravilu od trenutka narudžbe do trenutka kada je knjiga na raspolaganju korisniku prolazi 7-10 dana), to nije tako i za strane naslove. Na strane se naslove čeka znatno dulje. Kako korisnici publikaciju traže u trenutku kad im je potrebna, može se pretpostaviti da je dulje čekanje na njezino pribavljanje njima teško prihvatljivo i da će svoju potrebu nastojati namiriti na drugi način (druga knjižnica, posudba, kopiranje i sl.).

- Pogrešna procjena potrebe od strane korisnika - jednako kao što korisnici u Knjižnici često zatraže veći broj knjiga, od kojih dio vrate nakon letimičnog pregleda sadržaja, a samo manji dio zaista i posude, moguće je da tražena publikacija svojim sadržajem ne odgovara stvarnim potrebama korisnika te tu publikaciju neće ni zadužiti.

- Pristup publikaciji omogućen je na neki drugi način - korisnik može do građe doći na druge načine, od kojih svi čak ne moraju biti ni legalni (skeniranje, kopiranje i distribucija ispitnih i drugih materijala bez dozvole autora i sl.).

- Promjene u studijskim programima - predmetni silabusi i popisi potrebne literature mijenjaju se, čime se otežava nabava publikacija na temelju tih izvora.

Sasvim je sigurno moguće pronaći i više razloga, no ovi se mogu smatrati najizglednijima. Ovaj primjer također pokazuje da nije dobro temeljiti kriterije nabave uglavnom na zahtjevima korisnika, iako te zahtjeve uvijek moramo zaprimiti i procijeniti, a korisnika obavijestiti o odluci i razlozima zbog kojih je donesena.

\section{Pokazatelji kvalitete i zadovoljstvo korisnika knjižničnim fondom SVKRI}

Vrednovanje fonda koji SVKRI izgrađuje provodi se redovito i pritom se fond promatra kao cjelina. Na godišnjoj se razini prikuplja niz statističkih podataka iz kojih se potom izračunavaju pokazatelji kvalitete, a sve u okviru sustava osigu- 
ravanja kvalitete na razini Knjižnice i Sveučilišta. Na godišnjoj se razini prate pokazatelji kojima se mjeri primjerenost i raspoloživost zbirke, i to raspoloživost traženih naslova i postotak traženih naslova u fondu. ${ }^{29}$ Pokazatelj raspoloživosti traženih naslova procjenjuje vjerojatnost da je slučajno odabran naslov koji knjižnica posjeduje ili je dostupan pod licencom u trenutku kada je zatražen od strane korisnika. Visoki rezultat znači i visoku dostupnost. Slika 7 prikazuje kretanje tog pokazatelja u promatranom razdoblju.

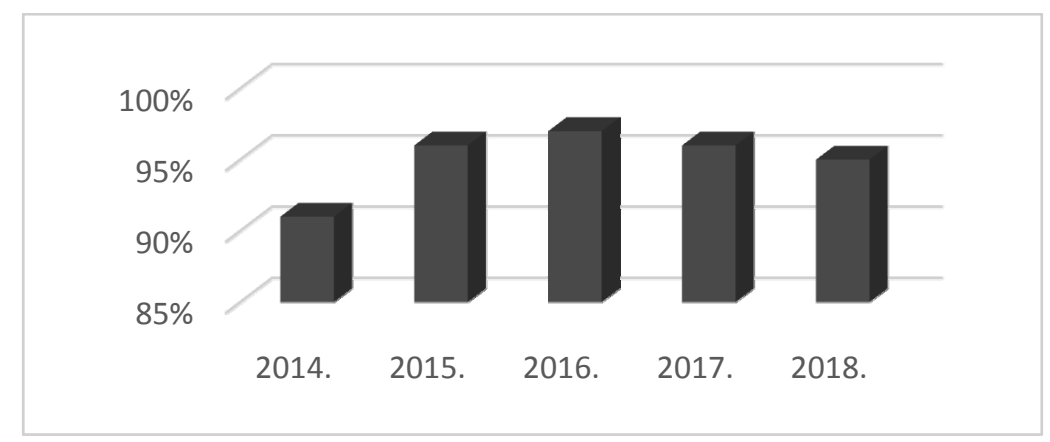

Slika 7. Raspoloživost traženih naslova u razdoblju od 2014. do 2018. ${ }^{30}$

Na slici 7 vidljivo je da je raspoloživost naslova u cijelom promatranom razdoblju na zaista visokoj razini. No taj pokazatelj zbog specifičnosti načina izgradnje fonda Knjižnice ne pokazuje potpuno stvarnu situaciju. Zbog primanja obveznog primjerka većina je naslova zaista i raspoloživa. No zaprimljeni obvezni primjerak nije građa koju je dopušteno iznositi iz Knjižnice, već se koristi samo u njezinu prostoru. Često to korisnicima ne odgovara, a ta je činjenica razlog što je u prioritete za kupnju građe uvrštena građa koja je tražena, a Knjižnica posjeduje samo obvezni primjerak.

Postotak traženih naslova u fondu drugi je pokazatelj koji se izračunava i prati na godišnjoj razini. Njime se procjenjuje vjerojatnost da se naslov koji je zatražio korisnik nalazi u knjižničnoj zbirci. U SVKRI je taj pokazatelj niz godina na razini $100 \%$, a razlog tomu jednak je kao i za prethodni pokazatelj, s time da treba napomenuti kako SVKRI može mjeriti samo ono što zaista i dozna od korisnika, odnosno što može pratiti kroz knjižnični program ili na druge načine. Knjižnica naprimjer ne može doći do informacije o neuspjelim upitima u bazi, odnosno o građi koju su korisnici tražili u internetskom katalogu Knjižnice i koju nisu pronašli. Mogućnost praćenja takvih upita zasigurno bi dala bolju sliku o tome što

29 Sveučilišna knjižnica Rijeka. Naputak za primjenu pokazatelja kvalitete knjižnične djelatnosti u Sveučilišnoj knjižnici Rijeka. [citirano: 2019-09-07]. Dostupno na: https://svkri.uniri.hr/images/kvaliteta/Naputak_za_primjenu_pokazatelja_2016.pdf.

30 Podaci dostupni u godišnjim izvješćima o radu i poslovanju za 2013., 2015. i 2018. [citirano: 2019-09-07]. Dostupno na: https://svkri.uniri.hr/index.php/o-nama/dokumenti. 
korisnicima treba. Posebno se to odnosi na slučajeve kada potencijalni korisnik pretražuje katalog Knjižnice i na onome što (ne) pronađe temelji svoju odluku o učlanjenju u Knjižnicu.

Svoj rad u odnosu na korisnike Knjižnica provjerava i periodičnim provođenjem ispitivanja zadovoljstva korisnika. U okviru tog upitnika ispituje se i zadovoljstvo korisnika knjižničnim fondom. Slika 8 prikazuje kretanje prosječne ocjene zadovoljstva korisnika knjižničnim fondom .

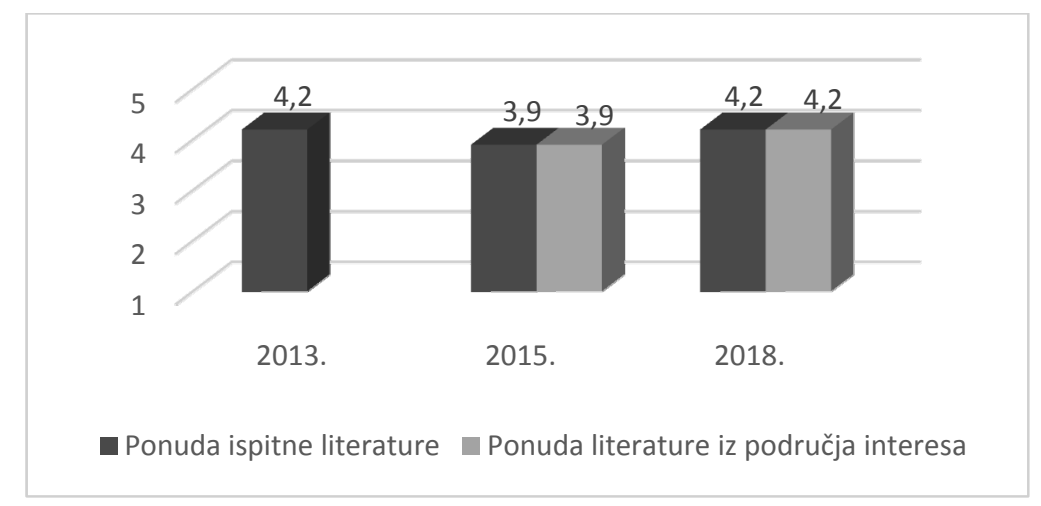

Slika 8. Kretanje prosječne ocjene zadovoljstva korisnika knjižničnim fondom ${ }^{31}$

Vidljiva je promjena u samom upitniku. Godine 2013. korisnicima je ponuđeno da ocijene samo ponudu literature i ta je ocjena bila visoka. U 2015. godini ukupna prosječna ocjena pala je na 3,9 , i to i za ponudu ispitne literature za kolegije na fakultetima i za ponudu literature iz područja interesa korisnika. U sljedećem trogodišnjem razdoblju ta ocjena ponovno se diže na 4,2. Vidljivo je da su korisnici zadovoljni i knjižničnim fondom.

Svi spomenuti pokazatelji i rezultati ispitivanja zadovoljstva korisnika odnose se na knjižnični fond u cjelini, bez obzira na način nabave građe. No s obzirom na to da su korisnici SVKRI većinom studenti te da tijekom studija u pravilu najviše trebaju ispitnu i seminarsku literaturu, može se smatrati da kupnja građe uvelike doprinosi ukupnom zadovoljstvu.

\section{Zaključak}

Izgradnja knjižničnog fonda koji će odgovarati misiji i viziji knjižnice i potrebama njezinih korisnika vrlo je složen postupak. Prinove se nabavljaju najčešće

31 Podaci dostupni u izvještajima o rezultatima ankete o zadovoljstvu korisnika SVKRI. [citirano: 2019-09-07]. Dostupno na: https://svkri.uniri.hr/index.php/o-nama/kvaliteta/9-o-knjiznici/225-aktivnosti. 
kupnjom, darom i zamjenom, odnosno na druge zakonom regulirane načine. Nabava građe za fond SVKRI kupnjom određena je Misijom i vizijom Knjižnice, potrebama korisnika i raspoloživim financijskim sredstvima. U okviru politike osiguranja kvalitete, Sveučilište u Rijeci niz godina Knjižnici osigurava dio sredstava iz studentskih upisnina koje je Knjižnica dužna namjenski trošiti na nabavu studentske ispitne i dodatne seminarske literature. Osim toga, Knjižnica sredstva za nabavu pronalazi kroz projekte koje provodi te manjim dijelom iz dostupnih vlastitih sredstava.

Jednom kada je građa pristigla u knjižnični fond, ona se vrednuje kao njegov sastavni dio. No kako je potrebno opravdati dodijeljena sredstva i dati argumente svaki put kada se od bilo kojeg izvora traže nova ili dodatna sredstva, potrebno je pomno analizirati trenutnu politiku nabave građe i procijeniti koliko je ona uspješna. Polazeći od jednostavnog kriterija da je uspješna kupnja one jedinice građe koju je korisnik barem jednom i zadužio, prikupljen je niz podataka iz raznih izvještaja generiranih iz knjižničnog programa, priručnih evidencija koje nastaju u postupku nabave i raznih izvještaja o svim segmentima poslovanja Knjižnice.

Analiza je pokazala da se u najvećem dijelu kupuje građa domaćih izdavača te da se ona najviše i koristi. Strani naslovi u većemu su obimu nabavljani za vrijeme trajanja projekta Američkog kutka, a posljednjih se godina nabavljaju tek sporadično, što odgovara izvorima financiranja koji su Knjižnici na raspolaganju. Analiza sadržaja kupljenih knjiga pokazala je da se najviše kupuju, ali i posuđuju knjige iz područja medicinskih znanosti, što se izravno dovodi u vezu s brojem članova Knjižnice koji studiraju na Medicinskom fakultetu i Fakultetu zdravstvenih studija, ali i s činjenicom da se radi o građi koja je skupa. Sadržajna struktura kupljenih knjiga odgovara strukturi studenata članova SVKRI.

Iako se najveći dio kupljene građe zaista koristi izvan Knjižnice ili kao dio Referentne zbirke u prostoru Knjižnice, s obzirom na ograničena sredstva za nabavu, potrebno je analizirati kupljene knjige koje se ne koriste. Najveći broj primjeraka koji su kupljeni, a potom nikada nisu posuđeni, iz područja je književnosti, a najmanji iz područja medicinskih znanosti. I tu prednjače knjige domaćih izdavača, što je očekivano s obzirom na omjer nabave domaće i strane građe.

Uvidom u priručne evidencije nastale u procesu nabave utvrđeno je da veći dio zahtjeva za nabavom nekorištenih primjeraka dolazi upravo od strane korisnika, što je iznenađujuće. Tomu može biti više razloga, od korisniku predugog čekanja na nabavu knjige do pronalaska drugog načina zadovoljenja potrebe. U budućnosti ostaje zadatak pomnije ispitati razloge.

No i do sada je Knjižnica redovito provodila ispitivanja zadovoljstva korisnika, a oni su joj davali visoku ocjenu i za knjižnični fond. Iako kupnja nije jedini način izgradnje fonda, ako se uzme u obzir da korisnik u pravilu knjigu želi koristiti izvan knjižnice, posebno kada se radi o studentima i znanstveno-nastavnom oso- 
blju kao najbrojnijim korisnicima SVKRI, kvalitetno provedena kupnja odgovarajućih naslova svakako doprinosi takvoj ocjeni.

Iako nije uobičajeno analizirati korištenost prema načinu nabave građe, već se obično promatra pojedina zbirka ili cijeli fond, zbog specifičnosti SVKRI to je bilo potrebno učiniti. Analiza provedena na ovaj način dobra je osnova za ocjenu daljnjeg postupanja u nabavi građe. Iako je za uparivanje podataka na taj način i manipuliranje njima potrebna veća količina vremena, povremeno je nužno utrošiti vrijeme i druge potrebne resurse kako bi se detaljnije analiziralo i ponašanje korisnika, ali i postupanje djelatnika. S obzirom na dobre rezultate koje je ova analiza dala, dobivene rezultate može se koristiti i u razgovorima s osnivačem, ali i za (samo)procjenu kvalitete poslovanja SVKRI.

\section{LITERATURA}

Ambrožič, M. Utvrđivanje uspješnosti poslovanja visokoškolskih knjižnica: od kvantitativnih do kvalitativnih pokazatelja: doktorska disertacija. Zagreb: M. Ambrožič, 1999.

Cheung, S.; T. Chung; F. Nesta. Monograph circulation over a 15 -year period in a liberal arts university. // Library Management 32, 6/7(2011), 419-434. DOI: https://doi. org/10.1108/01435121111158565.

Faletar Tanacković, S.; M. Junušić; I. Faletar. Vrednovanje knjižničnog fonda uz pomoć citatne analize na primjeru zbirke iz informacijskih znanosti u Knjižnici Filozofskog fakulteta u Osijeku. // Libellarium 5, 1 (2012), 71-88. [citirano: 2019-08-30]. Dostupno na: https://hrcak.srce.hr/97453.

Grujić, T. Nabava literature za potrebe Sveučilišta u Puli - možemo i bolje! // Knjižnice: kamo i kako dalje? / 13. dani specijalnih i visokoškolskih knjižnica. Zagreb: Hrvatsko knjižničarsko društvo, 2014. Str. 309-318.

Hyödynmaa, M.; A. Ahlholm-Kannisto; H. Nurminen. How to evaluate library collection: a case study of collection mapping. // Collection Building 29, 2(2010), 43-49. DOI: https://doi.org/10.1108/01604951011040125.

Izvješće o radu i poslovanju Sveučilišne knjižnice Rijeka za 2013., 2015. i 2018. [citirano: 2019-09-07]. Dostupno na: https://svkri.uniri.hr/index.php/o-nama/dokumenti.

Johnson, P. Fundamentals of collection development and management. 3rd ed. London: Facet publishing, 2014.

Krajina, T.; H. Markulin. Nabava knjižnične građe u visokoškolskim knjižnicama. // Vjesnik bibliotekara Hrvatske 54, 3(2011), 21-42. [citirano: 2019-08-29]. Dostupno i na: https://hrcak.srce.hr/80101. 
Mišetić, M. Vrednovanje filološke knjižnične zbirke u suvremenoj visokoškolskoj knjižnici: doktorski rad. Zagreb: M. Mišetić, 2017.

Morić Filipović, I.; M. Dragija Ivanović. Vrednovanje utjecaja sveučilišnih knjižnica u Hrvatskoj:istraživanje utjecaja zbirki i usluga sveučilišnih knjižnica na akademski uspjeh studenata. // Vjesnik bibliotekara Hrvatske 54, 4(2011), 1-12. [citirano: 201908-30]. Dostupno i na: https://www.hkdrustvo.hr/vjesnik-bibliotekara-hrvatske/index.php/vbh/article/view/337/332.

Petr Balog, K. Prema kulturi vrednovanja u visokoškolskim knjižnicama. Osijek: Filozofski fakultet Sveučilišta, 2010.

Prathap, G.; R. Mittal. A performance index approach to library collection. // Performance Measurement and Metrics 11, 3(2010), 259-265. DOI: https://doi. org/10.1108/14678041011098532.

Renaud, J.; S. Britton; D. Wang; M. Ogihara. Mining library and university data to understand use patterns. // The Electronic Library 33, 3(2015), 355-372. DOI: https:// doi.org/10.1108/EL-07-2013-0136.

Rezultati ankete o zadovoljstvu korisnika SVKRI. [citirano: 2019-09-07]. Dostupno na: https://svkri.uniri.hr/index.php/o-nama/kvaliteta/9-o-knjiznici/225-aktivnosti.

Romić, K.; G. Mitrović. Vrednovanje knjižničnog fonda: na primjeru zbirke disertacija i magistarskih radova u Nacionalnoj i sveučilišnoj knjižnici u Zagrebu uz pomoć citatne analize. // Vjesnik bibliotekara Hrvatske 59, 3-4(2016), 47-62. [citirano: 201908-30]. Dostupno i na: https://hrcak.srce.hr/187570.

Sveučilišna knjižnica Rijeka. Kriteriji i postupak kupnje knjižnične građe za fond Sveučilišne knjižnice Rijeka: smjernice za rad. Interni akt usvojen 01. veljače 2016. Dostupno u arhivi Sveučilišne knjižnice Rijeka.

Sveučilišna knjižnica Rijeka. Naputak za primjenu pokazatelja kvalitete knjižnične djelatnosti u Sveučilišnoj knjižnici Rijeka. [citirano: 2019-09-07]. Dostupno na: https:// svkri.uniri.hr/images/kvaliteta/Naputak_za_primjenu_pokazatelja_2016.pdf.

Sveučilišna knjižnica Rijeka. O Američkom kutku. [citirano: 2019-08-26]. Dostupno na: https://svkri.uniri.hr/portal/index.php/component/content/category/14-acri.

Sveučilište u Rijeci. Broj studenata u 2018./19. ak. godini. [citirano: 2019-09-10]. Dostupno na: https://rektor.uniri.hr/files/SVE\%20GODINE\%20STUDIJA\%20 2018_2019\%20tab\%20zavrsna\%20za\%20web.pdf.

Sveučilište u Rijeci. Strategija 2014.-2020. [citirano: 2019-08-26]. Dostupno na: https:// uniri.hr/wp-content/uploads/2019/03/Strategija_UNIRI_2014_2020_HR.pdf.

Zakon o knjižnicama i knjižničnoj djelatnosti. // Narodne novine 181, 17(2019). [citirano: 2019-08-26]. Dostupno na: https://narodne-novine.nn.hr/clanci/sluzbeni/2019_02_17_356.html. 